\title{
An Answer to the Plant Variety Controversy in Chile
}

\author{
Viola Prifti \\ Bournemouth University
}

Chile has failed to ratify the 1991 International Convention for the Protection of New Varieties of Plants (UPOV) as stipulated in the free trade agreement (FTA) with the United States. Since Chile is amongst the US Priority Watch List countries, it is imperative for Chile to emanate a UPOV 1991-compliant law. The ratification of UPOV 1991, however, has encountered strong resistance within the country and it is not yet clear when and how Chile will adopt UPOV 1991 provisions. Through an analysis of legal and economic aspects of the domestic plant variety law, this paper explains that Chile should make better use of UPOV flexibilities and gives recommendations in order to accommodate the interests of all stakeholders.

Keywords plant variety protection; farmers' privilege; free trade; Chile

Although the free trade agreement (FTA) ${ }^{1}$ with the United States requires Chile to ratify or accede to the 1991 act of the International Convention for the Protection of New Varieties of Plants (UPOV) ${ }^{2}$ before 1 January 2009, Chile continues to apply law nr. 19.342 on plant breeder's rights (PBR) in conformity with UPOV 1978. Despite attempts to abrogate this law and ratify the 1991 act of UPOV, law nr. 19.342 is still in force. The ratification process of UPOV 1991 in Chile started in $2009^{3}$ and was accompanied by broad social controversy because of its effects on Chile's economic progress (Jefferson, 2014, p. 35). For this reason, the Chilean President, Michelle Bachelet, withdraw the bill in 2014. Non-compliance with the FTA provisions on plant variety protection provides a basis for including Chile in the US Priority Watch List (Office of the United States Trade Representative, 2016, p. 49). As the US government may impose unilateral trade sections or initiate dispute settlement proceedings at the world trade organization (WTO) against countries included in the Watch List, it is important for Chile to design a plant variety protection law in line with its commitments under the US FTA and at the same time responsive to its socio-economic concerns.

This paper will offer guidance through an analysis of the legal controversy, interests of the parties involved, the legal and economic aspects of the proposed plant variety law and an exploration of UPOV 1991 flexibilities. To this purpose, the paper is organized as follows. Firstly, it briefly introduces the reader to the legal vicissitudes of the ratification process, the decision of the Constitutional Court of Chile and the interests of all the parties involved. Secondly, it compares the current plant variety protection law with the UPOV 1991-compliant proposal in order to better understand the controversy. Thirdly, it broadens the understanding of legal provisions through an economic perspective and empirical observations on plant variety certificates in Chile. Fourthly, it seeks an appropriate legal framework for Chile by investigating UPOV 1991 flexibilities as well as the interaction between plant variety and patent rights. Finally, it concludes and gives recommendations for a UPOV 1991-compliant law that promotes Chile's interests in plant breeding.

\section{The Proposal to Adopt a UPOV 1991-Compliant Law}

The process for adopting a national law in compliance with UPOV 1991 started on 3 March 2009 with the proposal of the Chilean President Michelle Bachelet. ${ }^{4}$ The bill, named "Monsanto Law" by populist movements (Jefferson, 2014, p. 39), encountered strong resistance from civil society. Farmers, various 
social groups and senators themselves denounced the negative effects of the proposed law on small-scale farming, food sovereignty and biodiversity. These concerns were especially emphasized in a petition in front of the Constitutional Tribunal of Chile. On 20 May 2011, 17 senators claimed the unconstitutionality ${ }^{5}$ of UPOV 1991, ${ }^{6}$ but the Tribunal rejected their petition. ${ }^{7}$ The grounds for the petition and the reasons for its rejection will be here briefly illustrated in order to better understand the matter at hand. The main arguments put forward by the senators were as follows:

1. The restriction of the farmers' privilege violates the right of property as established in art. 19. N. 24 of the Constitution. ${ }^{8}$

2. The provisions of UPOV violate the duty of the State to protect the preservation of the environment as required by article $19 \mathrm{n} .8$ of the Constitution and the scope of protection on plant varieties in UPOV 1991 obstacles the movement of goods. ${ }^{9}$

3. Violation of the State's duty to promote the harmonious integration of all sectors of the country and guarantee to the people the right to participate with equal opportunities in the national life as required by article 1, last paragraph of the Constitution.

4. Violation of the right to equality before the law (stated in article 19.n. 2 and n. 22 of the Constitution) considering that UPOV 1991 provides for no compensation for farmers that supply the genetic material possessed by the right holder.

The Tribunal dismissed these arguments as follows:

1. The contested rules do not relate with the right to acquire a private good, but with the protection and regulation of ownership. UPOV 1991 does not impede farmers to acquire ownership if their varieties comply with its requirements. ${ }^{10}$ Although farmers' varieties are not registered, they are commercialized through local channels. This means that there is established knowledge on these varieties and there is no need for registers. ${ }^{11}$

2. There is no direct relationship between UPOV and contamination of the environment ${ }^{12}$ and UPOV does not regulate the commercialization of plant varieties. Article 18 of the 1991 act clarifies that the breeder's right shall be independent of any measure taken by a Contracting Party to regulate within its territory the production, certification and marketing of material of varieties and that such measures shall not affect the application of its provisions.

3. The Tribunal decided that UPOV 1991 does not affect equality before the law. The formulation of the petition was deemed too generic since it did not specify how the Constitutional provision was violated. Thus it failed to provide the Tribunal the basis for a decision (p. 74). Similarly, the judges argued that the petition lacked sufficient elements to issue a verdict on a hypothetical violation of State's rights on the integration of the nation (p. 75).

The above arguments are undoubtedly thought-provoking but their analysis falls beyond the scope of this paper. The decision of the Constitutional Tribunal is yet relevant for the matter at hand as it offers important insights into the reasons for the controversy, and consequently helps find a solution. The decision reveals a clash between two major interests in plant breeding: those of commercial plant breeders and those of smallholder farmers. Commercial plant breeders are public institutions or breeding companies, which engage in creating new varieties of plants with enhanced qualities (to respond to consumers' preferences or climate conditions). Advanced biotechnological techniques and laboratory research allow these varieties to express identical characteristics through generations and control quality and yield performance. Smallholder farmers, on the other hand, often comprise indigenous people and families, who have undertaken plant breeding activities since time immemorial. They, however, do not 
have the technical and financial means to create the same varieties as commercial breeders. Farmers' varieties are heterogeneous and express distinctive features when replanted (Prifti, 2015a, pp.13-4).

To put it briefly, commercial breeders and farmers differ in two main aspects: financial resources and innovation models. ${ }^{13}$ These differences are reflected in the current controversy on plant variety protection in Chile. As underlined in the decision of the Constitutional Tribunal, UPOV does not protect smallholder farmers and indigenous people. These small innovators market their seeds through local and informal channels. Although this might induce to think that there is no overlap between farmers' and commercial breeders' system, the senators' petition claimed that the restriction of the farmers' privilege in UPOV 1991 creates difficulties for smallholders who cannot replant and exchange commercial seeds with each other. Social concerns on the economic impact of UPOV 1991 on small-scale farming were also one reason for the bill's withdrawal on 17 March 2014 (Jefferson, 2014, pp. 38-43). In order to better understand the matter and assess how UPOV protects these different interests, the following section will explain the UPOV system and compare the Chilean plant variety protection law with the UPOV 1991 bill. $^{14}$

\section{A Legal Perspective}

\section{Assessing Plant Variety Protection: UPOV 1991 Versus UPOV 1978}

UPOV aims at incentivizing breeders to create new varieties of plants through the grant of breeder's rights. Breeder's rights are a kind of intellectual property right that enable breeders to "capture a larger portion of the additional benefits generated by the cultivation of a new variety" (Eaton, 2007). Along with profitmaking, the object and scope of protection as well as duration of rights are other determinants designed to stimulate plant breeding activities. In this respect, the last UPOV amendment in 1991 introduces three main novelties: the obligation to protect all plant genera and species (article 3), a broader scope of protection (articles 14 and 15), a greater period of protection (articles 13 and 19). Under the precedent act, UPOV 1978, protection of all plant genera and species is only an option (article 4.1). The 1978 Act requires countries to protect a minimum of 24 genera and species, but at the same time it allows them to reduce the number of protected genera and species based on their special economic and ecological conditions. The lack of this flexibility in UPOV 1991 may be one concern for Chile.

Another novelty and concern of UPOV 1991 regards the scope of protection. Article 14 of UPOV 1991 covers the scope of the rights granted to the plant breeder, while its article 15 delineates some limits to the exercise of these rights. Based on article 14, breeder's rights extend to the protected variety, its essentially derived varieties (EDVs) as well as harvested material, and encompass additional acts such as conditioning for the purpose of propagation, exportation, importation and stocking for such purposes (article 15). UPOV 1978, on the other hand, provides that the rights of the breeder can be enforced only with regard to the production for commercial purposes, offering for sale and marketing of propagating material of the variety (article 5). It can be noticed from this brief comparison that UPOV 1991 grants a broader scope of protection not only by extending rights on the object of protection (EDVs, harvested material) but also by covering additional acts on protected material (exportation, importation and stocking).

The broader scope of protection granted to the breeder is further apparent in the "breeder's exception" and "farmers' privilege," new provisions contained in article 15 of UPOV 1991. The breeder's exception allows other breeders to use the protected variety as a source of variation for breeding other varieties, while the farmers' privilege is usually intended to permit farmers to save and replant protected seeds, and exchange them with other farmers. Breeders and farmers who commercialize protected products are nevertheless required to ask for a licence from the original breeder. These practices were already permissible under article 5 of UPOV $1978,{ }^{15}$ but it was article 15 of UPOV 1991 that made explicit the conditions under which breeder's rights are not deemed to be infringed. Its paragraph 1 makes the 
breeder's exception mandatory, whereas paragraph 2 gives countries the option to allow farmers using for propagating purposes, on their own holdings, the product of the harvest which they have obtained by planting, on their own holdings, a protected variety. ${ }^{16}$ The provision on farmers' privilege undoubtedly expands the scope of protection for breeders and reduces lawful activities for farmers. This restriction of the freedom to save and exchange seeds is one of the main controversies provoked by UPOV 1991 in Chile.

Article 13 of UPOV 1991 further strengthens breeder's rights by granting protection during the period between the filing or the publication of the application for the grant of a breeder's right and the grant of that right UPOV (2009b). During this period, the breeder is entitled to receive an equitable remuneration for acts that infringe his rights under article 14. As the period of provisional protection is added to the actual years of protection, the consequence of this provision is the postponement of third parties' market entry. The provisional protection of rights may generate worries with regard to access of protected varieties and may subsequently slow innovations in plant breeding. The same concerns exist on the length of protection; UPOV 1991 shifted the minimum years of protection from 15 to 20, and for trees and vines, from 18 to $25 .{ }^{17}$ In order to understand how the transposition of UPOV 1991 provisions into national legal systems may affect Chile, the following section will examine its legislative proposal for complying with UPOV 1991 in a comparative perspective with the current plant variety protection system based on UPOV 1978.

\section{UPOV 1978 Versus UPOV 1991 in Chile}

As aforementioned, Chile ratified UPOV 1978 with law no. 19.342. In order to better comprehend the controversy, the following table compares the object of protection and the scope of breeder's rights under this law and the bill drafted in compliance with UPOV 1991.

\section{Object of Protection}

As shown in Table 1, both legal acts protect plant varieties of all genera and species. Law no. 19.342 extends the object of protection to propagating material, while bill no. 8570 to hybrids. The language of their provisions differs; nevertheless, there are no substantial differences as regards the objection of protection under these legal acts. Propagating material, for example, falls under the scope of plant breeder's rights in the proposed law (article 39). Similarly, the explicit mention of hybrid varieties in the object of protection does not add much as hybrids are a type of plant variety bred through a hybridization process. ${ }^{18}$

\section{Scope of Protection}

The novelties of UPOV 1991 come to light with respect to the scope of protection. Table 1 shows the greater number of activities that fall under the scope of breeder's rights. In some cases, these activities are complementary to those already protected by law no. 19.342 (preparation of the material for propagation purposes, its advertisement and stocking) ${ }^{19}$; in others, they include new acts (harvested material, ${ }^{20}$ essentially derived varieties ${ }^{21}$ ).

One of the new provisions appears problematic: "varieties that are not clearly distinguishable from the protected variety" (article $39 \mathrm{c}$ ). The language of this provision suggests that breeder's rights may cover any variety, even those varieties developed independently from the protected variety. This seems to give not only a broader, but also an unreasonable scope of protection to the breeder. If the reason for granting breeder's rights is that of allowing breeders to "capture a larger portion of the additional benefits generated by the cultivation of a new variety" (Eaton, 2007), rewarding the breeder for varieties created without his contribution finds no justification. Extending breeder's rights to "not clearly distinguishable" varieties may thus generate additional profit for the breeder without a real contribution from his part. This will incentivize profit-making but not necessarily the creation of varieties with novel added value.

A further ill-advised effect of this provision may be that of extending breeder's rights to varieties which have been previously developed but not registered. It may happen that a breeder ameliorates an 
Table 1: Law No. 19.342 Versus Bill. No. 8570

\begin{tabular}{ll}
\hline Lbject of protection & \multicolumn{1}{c}{ Law no. 19.342} \\
& $\begin{array}{l}\text { Article } 3 \\
\text { Plant variety and propagating material } \\
\text { of all genera and species. } \\
\text { Article } 3\end{array}$ \\
a) Production of propagating material \\
of the variety. \\
b) Sale, offering for sale or display for \\
sale of the said material. \\
c) Marketing, import or export thereof. \\
d) Repeated use of the new variety for \\
the commercial production of \\
another variety. \\
e) Use of ornamental plants or of parts \\
of such plants that are normally \\
marketed for purposes other than \\
propagation, with a view to the \\
production of ornamental plants or \\
cut flowers.
\end{tabular}

Private use and

Article 3

Bill no. 8570

Plant varieties and their hybrids of all genera and species.

Article 39

a) Preparation of the material for propagation purposes.

b) Production of propagating material of the said variety.

c) Sale, offering for sale, advertisement or display for sale of the said material.

d) Marketing, import or export thereof.

e) Repeated use of the new variety for the commercial production of another variety.

f) Stocking for any of the purposes mentioned above.

g) Use of ornamental plants or of parts of such plants that are normally marketed for purposes other than propagation, with a view to the production of ornamental plants or cut flowers.

Article 39, part 2

a) The harvested material, including entire plants and parts of plants, obtained without authorization, unless the holder has had reasonable opportunity to exercise his right in relation to such material.

b) Varieties essentially derived from a protected one, unless the protected variety is an essentially derived variety itself.

c) Varieties that are not clearly distinguishable from the protected variety, according to the distinctiveness criterion established in article $7^{22}$ of this law.

Article 49

experimental

exceptions

a) Acts done privately with no commercial purposes.

continued 
Table 1: (Continued)

Bill no. 8570

Breeder's exception

Farmers' exception

Compulsory licences

\section{Article 5}

Create a new variety without having to seek the authorization of the breeder of the original variety that served as the means for breeding the new one. The authorization of the breeder is required where the variety has to be used continually for the production of a new variety.

Article 3, last paragraph

Use, on his own farm, of the harvest from properly acquired reproductive material. On no account, however, may such material be advertised or transferred by any legal title as seed.

Article 7

If a breeder is in a situation of monopolistic abuse in the exploitation or marketing of the protected variety. b) Acts done for experimental purposes.

Article 49, c)

Acts done for the purpose of creating new varieties and the acts listed in Article 39 unless they regard: essentially derived varieties or varieties not clearly distinguishable from the protected variety, or varieties whose production requires the repeated use of the protected variety.

Article 48

Use for propagating purposes of the harvest obtained from the planting of a lawfully acquired protected variety other than hybrid or synthetic, on his own holdings. It is expressly prohibited the sale or alienation by any title of the propagative material.

This right can be exercised on the species Solanum tuberosum L. (potato) and on cereals; legumes and seed propagated species determined by the regulation.

\section{Article 45}

a) If the breeder has engaged in conducts or practices declared contrary to free competition, in direct relation with the use or exploitation of the variety in question, according to final and executive decision of the Tribunal of Defense of Free Competition, in conformity with current legislation.

b) When for reasons of public health, national security, public noncommercial use or national emergency, extreme urgency or others that are of public interest, declared by the competent authority, (...).

Note: The terms in italic indicate those provisions added by the bill. For the duration of breeder's rights and their provisional protection, the considerations elaborated above remain valid and are not shown in the table. The bold part of the provision indicates the restriction of the farmers' privilege.

existing variety and obtain protection even if the new variety is not clearly distinguishable. This can occur when the original variety is not a matter of common knowledge ${ }^{23}$ and thus does not come into question when assessing the "distinctiveness" requirement. This situation may create the paradox of allowing the breeder to claim his rights on the variety which enabled him to undertake the breeding process. 


\section{The Breeder's Exception}

Other novelties introduced by the bill regard the exceptions to breeder's rights. Although the breeder's exception continues to allow other breeders to use the protected variety in their breeding lines, the bill clarifies that EDVs or not clearly distinguishable varieties do not fall under the exception. This means that the breeder should ask for a licence not only if he commercially produces varieties bred with the protected variety, but also if he simply uses EDVs and not clearly distinguishable varieties in his breeding programmes. Besides broadening the scope of breeder's rights, envisaging acts on EDVs and not clearly distinguishable varieties as infringing creates difficulties for compliance. This is because it is not easy to determine what an EDVs is and when a variety is not clearly distinguishable from a protected one (International Convention for the Protection of New Varieties of Plants, 2013). Large plant breeding companies may be well-equipped to conduct such an investigation, but small farmers and indigenous communities clearly lack the necessary resources to determine when a variety is an EDV or when it is not clearly distinguishable from a protected one. They might thus very often infringe PVP provisions.

\section{The Farmers' Exemption}

The current plant variety protection law does not make use of the seed-saving exemption of UPOV 1978. The bill reaffirms the seed exchange prohibition and puts further limitations. Whereas it continues to permit seed-saving from the product of the harvest on farmer's own farm, it explicitly excludes saving of hybrid and synthetic seeds. ${ }^{24}$ The right to save propagated material can be exercised on the species Solanum tuberosum L. (potato) and on cereals; legumes and seed propagated species determined by the regulation. ${ }^{25}$ Although the provision allows seed saving for potatoes, cereals, legumes and other seedpropagates species, its applicability is more limited than it might appear. This is because many of the marketed cereals and legumes are hybridized. ${ }^{26}$

The applicability of this provision would be further reduced if marketed varieties were genetically modified. The consequence would be the impossibility to save seed. Although this is not the present situation, it may be a possibility in the future. ${ }^{27}$ Hence this provision may be deemed too restrictive, especially for those farmers who need to save seed for their subsistence. In this specific context, seed exchange is a must in order to enhance farmers' livelihoods and food security. In a more general context, seed exchange would enable technology transfer and broaden the base of genetic variety for breeding new plants. This is not permitted by the provision on farmers' privilege in the revoked bill.

Besides restricting seed practices only to own harvest on own's holdings, ${ }^{28}$ the provision allows sale of farmers' products to third parties for final use or consumption. ${ }^{29}$ This interpretation of the farmers' privilege seems to outlaw informal credit practices. In Latin America, farmers sell their harvest to grain dealers who provide it as a credit in kind to other farmers. These farmers use the credit as seed and pay off with the double quantity of the seeds obtained (van Wijk, 1996). ${ }^{30}$ Under the farmers' privilege, informal credit might become illegal. This is because the sale of harvest to grain dealers is not intended either for final use or consumption. Similarly, the payoff of the credit in kind would not fall under the exemption.

\section{Compulsory Licensing}

Another restriction of breeders' rights is found in the provision on compulsory licensing. While law no. 19.342 provides for compulsory licences only in case of monopolistic abuse in the exploitation or marketing of the protected variety, the abrogated bill lists two grounds for compulsory licensing: a) conducts or practices declared contrary to free competition, in direct relation with the use or exploitation of the variety in question and b) reasons of public health, national security, public noncommercial use or national emergency, extreme urgency or others that are of public interest, declared by the competent authority. 
The reference to "public interest" broadens the grounds for compulsory licensing. "Public interest" is an all-inclusive concept that gives the competent authority extensive freedom to determine the reasons for compulsory licensing. In the case of uncompetitive behaviour or practices, the interpretation of the terms "in direct relation with the use or exploitation of the variety in question" is decisive. "Direct" acts are those acts that "bear immediately and unambiguously upon the facts at issue" 31 and are connected to the variety in a clear way. ${ }^{32}$ Conversely, indirect acts are those acts not directly aimed at the variety. Direct acts can occur, for instance, when breeders agree to divide territories and reduce competition in these territories or when they require exclusive dealing with distributors by contract.

The effect of these acts can be directly related to the variety as they immediately bear upon the distribution of the variety. But it is not always easy to distinguish between direct and indirect acts on the variety. An example can be the practice of tying the purchase of fertilisers with protected seeds. This practice may be seen as indirectly related to the sale of fertilisers if seed of a substitutable variety is available on the market. If, on the other hand, the protected seed is a unique product required for its particular traits (draught tolerance, resistance to a specific disease), tying should be considered as directly related to the variety. Both these acts can equally result in the restriction of free competition. Thus it does not seem appropriate to base compulsory licensing only on acts in direct relation with the variety.

Another case of indirect acts that affect free competition may be that of a plant breeding company purchasing another competitor with the intention of acquiring possession of one of its breeding lines. Since control of breeding lines may be an indirect consequence of the takeover, it may be difficult to relate the purchase of the company with the intention to acquire a specific variety. For this reason, it is not clear why the legislator does not take account of indirect acts as a basis for compulsory licensing.

\section{Exhaustion of Rights}

Besides the above articles, the bill contains a new provision on the exhaustion of breeder's rights in its article 50. The first part of this article establishes that rights on plant material, harvested material, including whole or parts of plants are extinguished with the sale of the protected variety by the right holder or with his consent, while the second part exempts from this rule acts that involve further propagation of the variety in question as well as activities relating to the export of material of the variety, which enable the propagation of the variety in a country where there is no protection of the plant variety in question, except if the variety is intended for consumption.

The first part of this provision reflects article 16 of UPOV 1991. Its rationale could be explained by a recent US Supreme Court decision on the exhaustion of patent rights related to biological material. ${ }^{33}$ Unlike other intellectual property rights, which exhaust with the first sale of the protected product or process by the IP owner or with his consent, the US judges clarified that the exhaustion doctrine as applied to protected biological material does not permit a farmer to reproduce patented seeds through planting and harvesting without the patent holder's permission. ${ }^{34}$ Similarly, it can be argued that breeder's rights do not permit farmers to reproduce protected seeds through planting and harvesting without the breeder's permission. Though this may be advisable from a right holder's perspective, its effect on innovation is questionable. Farmers that need to use protected seeds would need to ask for a licence. Not all of them can be successful because licensing usually comes with high royalties and transaction costs. If licensing fails, creation of new varieties and the transfer of the technology embedded in the protected biological material will be impeded.

The restrictive effects of this provision for innovation become more apparent in its second part. There is no good reason to prohibit the exportation of propagating material in a country where there is no plant variety protection. If the rationale of plant breeder's rights is that of rewarding breeders for improving plant varieties, the reward can be obtained from selling and licensing their varieties in the country where rights are granted. In a country with no PVP protection, breeders can sell their varieties but cannot exercise 
other PVP-related acts such as licensing and prohibition of seed-saving practices. It could be argued that the breeder may nevertheless be disincentivized to market his varieties in a country where other breeders could freely reproduce the original variety and offer it at lower prices. ${ }^{35}$

This may be especially the case of varieties bred to resist climate conditions specific to the country. Here the question would be whether the lead time enables the original breeder to recoup his R\&B costs. The answer will depend on the type of variety and the technical capacities of other breeders. In developing and least developed countries, it may not be easy for domestic breeders to reproduce the original variety. Even if they had the capacities, technical constrains do not allow reproduction of the variety. In the case of hybrids, for example, finding parental lines requires advanced technological methods and considerable time. The reproduction of GM varieties can only be performed by specialized companies in the sector. If such companies are not in the market, the profits of the original breeder may be curtailed only by seedsaving.

It is, however, not easy to conclude a direct correlation between profit curtailment and disincentive to invest. ${ }^{36}$ Moreover, farmers are unable to produce for large markets and their varieties are of lower quality than those of the original breeder. Thus, a clear answer cannot be provided. In any case, it appears unfounded to prohibit exportation to countries with no PVP, especially when the activities of foreign breeders do not enter into competition with that of the original one (when the 2 nd breeder improves the variety in order to develop a different one). ${ }^{37}$ From a consumer's perspective, the provision may, nevertheless, have some positive outcomes because it allows for exportation of propagating material intended for consumption. As the provision does not clarify whether "consumption" is intended for humans or animals, it can be argued that propagating material intended both for feed and food use is authorized.

\section{Offenses and Sanctions}

A last aspect to be mentioned in a comparison between law no. 19.342 and the bill are their provisions on offenses and sanctions. ${ }^{38}$ Articles 44-46 of law no. 19.342 lay down penal, civil and administrative sanctions for acts that infringe the rights of the breeder. Penal sanctions in the context of plant breeding can be disproportionate. They can put an unjustifiable burden on farmers who have traditionally engaged in seed saving practices. As farming practices are embedded in the traditions and culture of a country (Louwaars, 2007), an immediate change is difficult. Traditional agricultural practices are handed down from generation to generation and have become institutionalized in the society. ${ }^{39}$ A change in their behavioural patterns is possible but it requires time. ${ }^{40}$ Moreover, farmers are often uninformed on legal changes and thereby, unaware of IP rights on seeds or prohibitions of practices that they consider "normal." These are some of the difficulties that farmers would face under this law.

Interestingly, articles $51-56$ of the revoked bill contained only civil sanctions ${ }^{41}$ but they add new prohibitions such as the use of a different denomination for the protected variety; omission of the denomination of the variety that corresponds to propagating material and labelling, classification and indication of consumer products as seeds and/ or of seeds as consumer products when they are not (article 51). This provision seems too demanding for farmers as they are not always aware of the denomination of the variety or they may have their own informal denomination system. Imposing formal names may go against their traditional cultural expressions. ${ }^{42}$

The analysis conducted so far denotes that the bill expands the rights of breeders and at the same time highly restricts permissible activities for farmers. Though to a lesser extent, the same trend is noticed in law no. 19.342 which does not make use of the flexibilities of UPOV 1978. It appears thus that the current plant variety protection law in Chile has already adopted UPOV 1991 provisions on the protection of all genera and species as well as on farmers' privilege. In order to take account of farmers' concerns on strong breeder's rights, it is important to understand whether breeder's rights can be weakened. 


\section{Can Plant Breeders Rights Be Weakened?}

Limits to plant breeder's rights are contained in the UPOV Convention itself. As explained above, breeder's rights do not extend to private and non-commercial use, experimental and breeding activities, and to some farming practices. Hence the answer to this question is positive. The issue is whether these limits have a rationale. The justification for limits to PBRs can be found in economic studies. Neoclassical economic theory claims that strong proprietary rights lead to more innovation and societal welfare in the long term. Although this theory has been recently debated (Andersen and Konzelmann, 2008, pp. 12-28; Boldrin and Levine, 2008; Cimoli et al., 2014; Greenspoon and Cottle, 2011). Provisions on intellectual property rights continue to be based on the neoclassical view. This view, also shared by the plant breeding community (American Seed Trade Association, European Seed Association, International Seed Federation $)^{43}$ hinges on the necessity to grant intellectual protection as an incentive for innovation.

Its theoretical and empirical investigation in plant breeding has been object of fewer studies compared to analysis in other technological areas. The reason lies in the inherent characteristics of plant varieties, which make it very difficult to provide general results for the whole sector. Depending on individual variety features such as the type of pollination or yield, the results may vary from variety to variety. The decision to invest in particular crops may additionally be an outcome of market demands or other incentives (e.g. subsidies). Present studies have been mainly conducted on the most important commercialized crops such as soybean, maize, rice, cotton, etc. and have investigated the effect of PBRs on $R \& D$, the number of the varieties released, market concentration, research priorities and access to varieties. Their results have, however, been mixed (Goldsmith et al., 2007, p. 19; Endres and Giffin, 2012, pp. 203-53; Rangnekar, 2001).

The heterogeneity of the results is comprehensible given the divergence between the socio-economic conditions of different countries and the diverse variables used in these studies. To put it simple, current investigations do not allow drawing clear-cut conclusions on a direct link between PBRs and incentives to innovate. They do, however, show that PBRs allow breeders to generate profit and better appropriate their R\&B costs. The positive link between PBRs and profit has been shown in one empirical study in Argentina, Brazil, China, India and the United States. This study found a statistically significant correlation between R\&D and hectares planted, but not crop yield (Endres and Giffin, 2012, pp. 209-10). Breeders have more gains by selling seed for each planted hectare as compared with crop yields. Crop yields, on the other hand, benefit more farmers. An earlier study provided similar arguments for Chile (Jaffé and van Wijk, 1995). The grant and enforcement of plant breeder's rights enabled private firms to obtain a better return on R\&B but no convincing evidence was found between IP rights and the rate of innovation.

This situation points to the importance of other factors in the development of plant breeding ${ }^{44}$ and allows inferring that weaker rights for plant breeders may reduce profit-making but not necessarily the incentive to innovate. ${ }^{45}$ As the object of PBRs is not profit-making but that of stimulating plant breeding activities, weaker rights may be justified when countervailed against other deserving interests. Some European countries, for example, have impaired patent rights for biotechnological innovations to favor plant breeding activities despite the role of patents in biotech innovations (Prifti, 2015b). The scope of rights is determinant in preserving innovation in the sector. In this regard, a theoretical model developed for plant breeding suggests that exemptions to rights on plant varieties are desirable when R\&D expenditures are high (Moschini and Yerokhin, 2007, pp. 190-203). This may indicate the undesirability of weaker rights on plant varieties as breeding costs are quite high. But this model does not take account of social welfare effects. If the model added societal implications to the private incentive effects, the results might differ. Thus, the question of defining the scope of weaker rights in plant breeding remains open.

One study on the soybean industry has, however, shown that the farmers' privilege does not decrease the incentive to invest and there is no need for stronger property rights (Hansen and Knudson, 1996, 
pp. 403-14). The findings of this study can be further understood in a broader context. As mentioned above, limited patent rights that benefit breeding activities have already been accepted by the European legislator as an incentive to innovate and increase innovation in plant breeding activities despite their commercial intent. Hence it appears incongruous to believe that limiting plant breeder's rights to permit seed-saving and exchange would affect the incentive to invest in new varieties. Smallholder farmers and indigenous communities do not engage in commercial activities but in subsistence farming to provide for the needs of their families and eventually, the village. This implies that their varieties do not reach commercial markets and consequently, do not enter into competition with plant breeders. Weakening breeder's rights can also bring benefits to the breeders themselves as traditional farming practices enhance biodiversity and offer a wider range of plant genetic material for commercial breeding (Correa, 2000b, pp. 10-1; GIZ Deutsche Gesellschaft für Internationale Zusammenarbeit GMbH, 2015, p. 27; de Jonge and Munyi, 2015, p. 12). Allowing these activities in Chile would be especially important for its economic growth. An investigation of the Chilean plant breeding market might offer other elements in support of this reasoning.

\section{A Chilean Perspective on Plant Variety Protection}

As mentioned above, Chile has provided for plant variety rights driven by the need to stimulate innovation in plant breeding. The US-Chile FTA objective, stated in its preamble, to promote social welfare and sustainable development seems to be another reason for fulfilling the obligation to ratify UPOV 1991. The potential of free trade to maximize national welfare justifies this aim (Chipman, 2008; Irwin, 2005, pp. 2552; Krugman, 1996; Ricardo, 1971; Trebilcock, 2011, pp. 4-10). The Heckscher-Ohlin model suggests that trade particularly increases welfare in countries with different factors of production and technology (Feenstra, 2004, pp. 31-63). ${ }^{46}$ The benefits that FTAs bring to developing economies are, nevertheless, not clear. One reason is the difficulty to define the effect of IP trade-related provisions on innovation, foreign direct investment and technology transfer (Correa, 2000a, pp. 23-48). A multitude of factors influence the effect of IP provisions and moreover, the effects vary according to the technological sector (Fink and Primo Braga, 2005, pp. 19-40). Despite this ambiguousness, Chile has agreed to provide for plant variety rights under the US FTA.

The question thus is not whether to adopt UPOV 1991 provisions but how to adapt them to the Chilean socio-economic conditions. It was previously explained that strong plant breeder's rights negatively affect farmers' freedom to perform their daily activities. This is the main concern of the heated controversy on plant variety protection. As there seems to be a tendency towards stronger IP rights on international level, lowering the threshold of protection of IP rights incorporated in a FTA requires a sound justification both from an IP and trade perspective.

Weak IP rights involve a trade-off between dynamic and static efficiency. When rights are weakened, they allow third parties to benefit from accessing new knowledge and products that would otherwise be excluded from the public domain. This creates a static efficiency. Neoclassical economic theory, however, suggests that this situation may give rise to dynamic inefficiency in the future as weaker rights may give breeders no incentive to innovate. A solution to this dilemma is of fundamental importance for developing countries in order to achieve economic growth and reduce the knowledge gap that divides them from developed countries (Dosi and Stiglitz, 2014,p. 1). Besides access to knowledge, several other factors such as missing or weak infrastructure, poorly functioning agricultural markets and a lack of investment hinder economic growth in developing countries (Food and Agriculture Organization, 2014).

Trade is believed to be a remedy to these deficiencies by promoting a more efficient allocation of resources, transfer of knowledge, technological progress as well as domestic and international competition (Grossman and Helpman, 1991; Krugman, 1979, pp. 253-66). More importantly, trade facilitates 
economic development. ${ }^{47}$ Trade is a means to improve economic growth, and thus human welfare, not an end in itself (Horlick, 2011, p. 395). It should be noted that economic growth allows for distributional effects which may be desirable or not for society. If undesirable, the development gap within the country and between countries will deepen. Therefore, it seems advisable to view trade "as one of several mechanisms to balance various social welfare objectives, including but not limited to innovation" (Chon, 2014, pp. 256-86; Sen, 1999). As clarified above, empirical investigations on the effect of trade-related IP rights on innovation are heterogeneous or absent in many sectors. Therefore, it is not possible to derive conclusions on how UPOV 1991 provisions will affect the plant breeding sector in Chile.

We can, however, obtain some indications on the impact of plant breeder's rights in the development of the seed market by observing the grant of plant variety certificates in Chile. The following diagrams show thus the share of proprietary market in different seed sectors. ${ }^{48}$

In Figures 1-4, we can notice that several countries hold plant breeder's rights. Foreign breeders appear to have a larger market share than Chilean breeders. In the tree sector, Chilean breeders are not active. Chile has the largest share for agricultural crops but a minor one for other sectors dominated by the

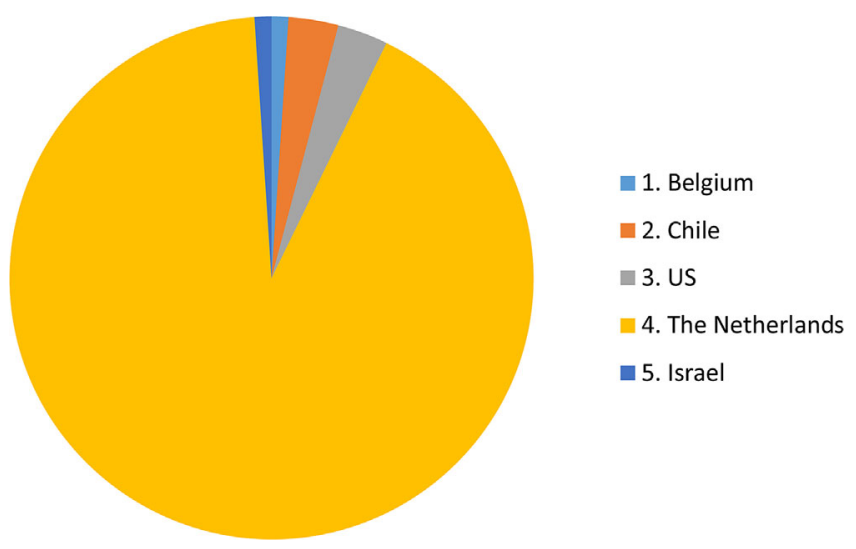

Figure 1. Share of proprietary market for ornamentals

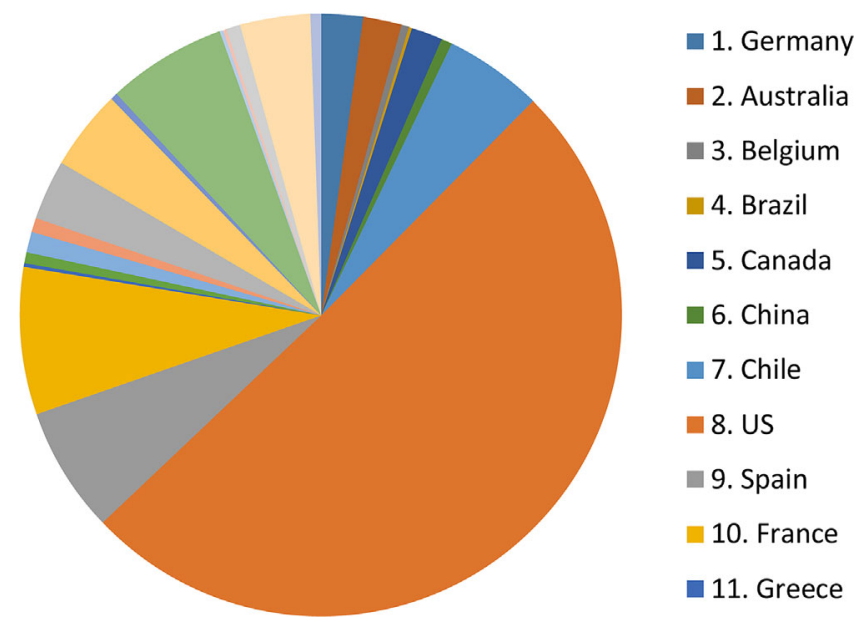

Figure 2. Share of proprietary market for fruits 


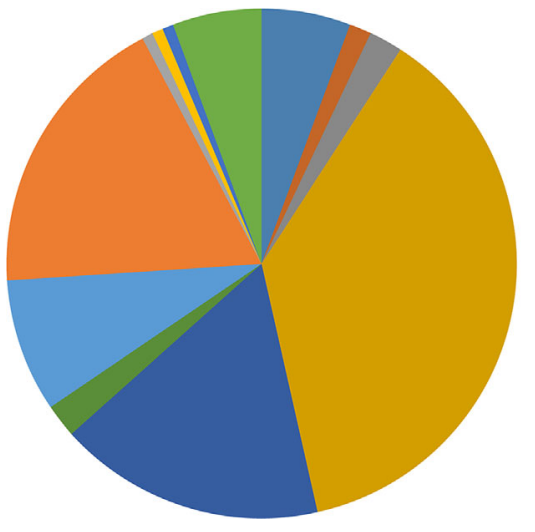

1. Germany
2. Argentina
$\square$ 3. Australia
4. Chile
$\square$ 5. US
$\square$ 6. Spain
7. France
$\square$ 8. The Netherlands
$\square$ 9. Irland
10. Italy

Figure 3. Share of proprietary market for agricultural crops

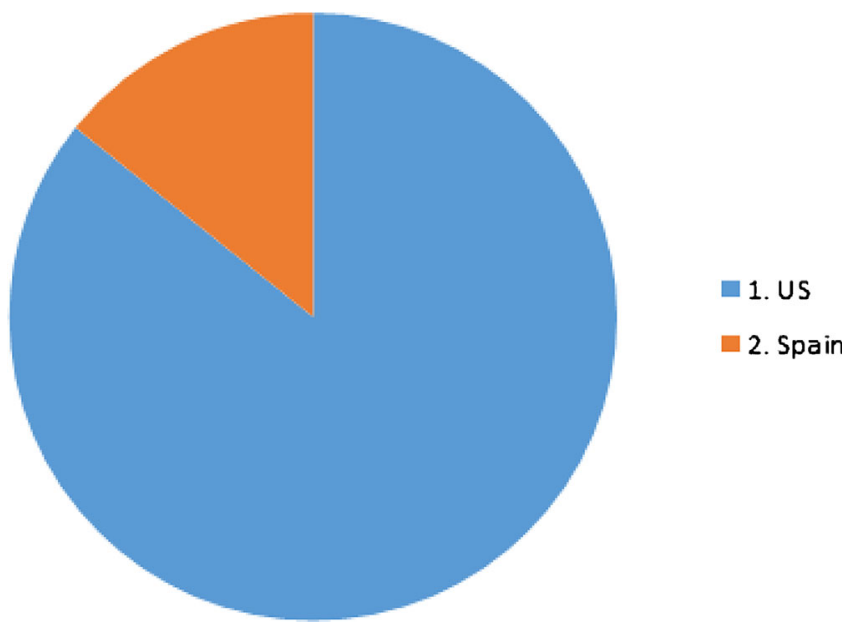

Figure 4. Share of proprietary market for trees

Note: The data were last updated on 13 July 2015 and the figures do not distinguish between provisional and definitive titles.

United States and the Netherlands. Table 2 shows the number of PVP certificates held by breeding companies in Chile in 2015. Of the 53 PVP certificates granted to Chilean breeders, 26 belong to public institutions and 27 to private firms. ${ }^{49}$ Chilean breeders engage in creating crops that are native to the country ${ }^{50}$ or form a substantial part of the Chilean diet such as avena, barley, beans, lupus, maize, oregano, potatoes, red clover, triticale and wheat (Umaña-Murray, 1996). ${ }^{51}$

Potato breeding is carried out by public breeders who are also active in wheat breeding. Twelve PVP certificates in wheat varieties are awarded to public companies while 11 certificates to Erik von Baer, the only private breeder of wheat in Chile. Although it is not wise to draw general conclusions, this situation gives rise to two considerations in terms of the issue at hand. The first pertains to the economic theory on the incentive to invest as a means of spurring innovation. This theory does not hold when publicly funded firms undertake breeding activities. This is because investment in variety improvement of important staple crops, such as the potato in Chile, is an objective of national agricultural programmes and funds will be dedicated independently of market incentives. Absence of market incentives, indeed, may be necessary for 
public intervention in order to ensure diffusion and access to essential crops. Market incentives are high when crop commercialization brings profit. Besides wheat, maize is another crop where private incentives to invest are strong.

Similarly to wheat, PVP certificates for maize are also granted to only one company, Agricola Panam Seed Service. This allows us to arrive at the second remark, which relates to the privileged position of seed companies. If there is only one company active in improving varieties of a species, it means that one sole breeder will determine seed prices and distribution. The time lead and the market advantage may allow the first breeder to recoup his breeding and development (B\&D) costs. There is no reason, thus, to object to a farmers' privilege that would allow farmers to carry out their normal farming activities such as seed saving and exchange. Table 2 provides a better understanding of the position of breeders in Chile by showing ownership of agricultural crops.

\section{Table 2: No. of Protected Agricultural Crops in Chile}

\begin{tabular}{lll}
\hline Species & No. of protected varieties & Company \\
\hline
\end{tabular}

\begin{tabular}{ll}
\hline 1. Artichoke & 6 \\
2. Lupinus luteus & 1 \\
3.Lupinus & 1 \\
$\quad$ angustifolius & 1
\end{tabular}

4. Lupinus albus L.

5. Rice

6. Pea

7. Avena

8. Avena negra

9. Hybrid ryegrass

10. English

ryegrass

11. Italian ryegrass

12. Bromus

13. Barley

14. Onions

15. Cilantro

16. Colza (rapseed oil)

17. Beans
1

1

1

6

1

1

1

1

3

2

1
Nunhems B.V.

Baroda Farms, Inc.

Centro de Genomica Nutricional Agroacuicola, CGNA

Western Australian Agriculture Authority, Grain Research and Development Corporation

Erik von Baer

Erik von Baer

INIA Chile

Instituto de Investigaciones Agropecuarias

Seminis Vegetable Seeds, Inc.

Erik von Baer

Noordsaat Saatzucht GmbH

The New Zealand Institute For Plant and Food Research

Limited

Panam France

PGG Wrightson Seeds Ltd.

PGG Wrightson Seeds Ltd.

\section{R.A.G.T.}

PGG Wrightson Seeds Ltd.

Instituto de Investigaciones Agropecuarias

Nordsaat Saatzucht GmbH

Erik von Baer

Secobra Recherche S.A.S

Seminis Vegetable Seeds, Inc.

Instituto de Investigaciones Agropecuarias

Seminis Vegetable Seeds, Inc.

Monsanto Technology LLC

Seminis Vegetable Seeds, Inc.

Alliance Semillas S.A.

Harris Moran Seed Company 
Table 2: (Continued)

\begin{tabular}{|c|c|c|}
\hline Species & No. of protected varieties & Company \\
\hline 18. Lactuca sativa & 3 & Seminis Vegetable Seeds, Inc. \\
\hline 19. Maize & 7 & Agricola Panam Seed Service \\
\hline \multirow[t]{2}{*}{ 20. Melon } & 4 & Seminis Vegetable Seeds, Inc. \\
\hline & 7 & Nunhems B.V. \\
\hline 21. Oregan & 1 & Fundación Chile \\
\hline \multirow[t]{12}{*}{ 22. Potato } & 3 & Instituto de Investigaciones Agropecuarias \\
\hline & 6 & HZPC Holland B.V. \\
\hline & 2 & Kweekbedrijf Ropta ZPC \\
\hline & 2 & KWS Potato B.V. \\
\hline & 1 & INIA Chile \\
\hline & 2 & Frito-Lay, Inc. \\
\hline & 1 & IPM Potato Group Ltd. \\
\hline & 1 & $\begin{array}{l}\text { Saka Pflanzenzucht GmbH Co. \& KG } \\
\quad \text { (Solana Resaerch } \mathrm{GmbH})\end{array}$ \\
\hline & 1 & Agrico B.A. \\
\hline & 1 & Europlant Pflanzanzucht $\mathrm{GmbH}$ \\
\hline & 2 & Solana Agrar Produkte GmbH and Go. $\mathrm{Kg}$ \\
\hline & 1 & Germicopa SAS \\
\hline 23. Orchard grass & 1 & R.A.G.T \\
\hline 24. Cucumber & 1 & Seminis Vegetable Seeds, Inc. \\
\hline 25. Quinoa & 1 & Erik von Baer \\
\hline 26. Raps/Colza & 1 & Forage Innovations Ltd. \\
\hline 27. Watermelon & 1 & Nunhems B.V. \\
\hline \multirow[t]{2}{*}{ 28. Tomato } & 2 & Nunhems B.V. \\
\hline & 2 & Seminis Vegetable Seeds, Inc. \\
\hline 29. White clover & 1 & Pyne Gould Guiness Ltda. \\
\hline \multirow[t]{4}{*}{ 30. Red clover } & 1 & Criadero El Cencerro S.A. \\
\hline & 1 & Semillas Biscayart SA \\
\hline & 1 & Instituto de Investigaciones Agropecuarias \\
\hline & 1 & ANASAC \\
\hline 31. Sub clover & 2 & South Australian Seed Growers \\
\hline \multirow[t]{7}{*}{ 32. Wheat } & 10 & Erik von Baer \\
\hline & 9 & Instituto de Investigaciones Agropecuarias \\
\hline & 1 & Nordsaat Saatzucht GmbH \\
\hline & 1 & ANASAC \\
\hline & 2 & Saaten Union Recherche S.A.S \\
\hline & 1 & Swlö Weibull Sarl \\
\hline & 1 & W. von Borries-Eckendorf GmbH \& Co. KG \\
\hline 33. Durum wheat & 3 & Instituto de Investigaciones Agropecuarias \\
\hline \multirow[t]{2}{*}{ 34. Triticale } & 1 & Instituto de Investigaciones Agropecuarias \\
\hline & 1 & INIA \\
\hline 35. Carrot & 2 & Nunhems B.V. \\
\hline
\end{tabular}

Note: Data updated as of July 2015 on the website of Servicio Agrícola y Ganadero, Chile. 
Despite some diversity in ownership of potato and wheat breeding, most of the protected varieties belong to one or two companies. The above table also shows that PVP certificates are granted only for 35 crops. Considering that the number of agricultural species, both domesticated and wild is higher, ${ }^{52}$ it may be argued that farmers are free to cultivate other species. Although this may be true ${ }^{53}$ most important Chilean crops such as wheat and potato are protected with plant variety certificates.

Concentration of staple crops in the hands of few breeders enables them to easily charge monopolistic prices and prevent subsistence farmers to cultivate varieties for family use. When prevented to save, replant and exchange seed, farmers face additional costs, such as the cost of storage and acquiring new seed (Ragavan, 2012, pp. 317-19). These difficulties combined with lack of sufficient financial resources might lead to food security problems, especially in marginalized areas and amongst indigenous population. At present, $5 \%$ of the Chilean population is undernourished. ${ }^{54}$ This seems a good reason to limit breeder's rights for the benefit of marginalized communities who have poor access to food. The importance of food security in limiting rights in plant breeding has already been argued in relation to patent rights (Prifti, 2015b, pp. 163-5). ${ }^{55}$ Whilst breeder's rights pose less food security concerns than patent rights in plant breeding, ${ }^{56}$ protected seeds may nevertheless impede smallholder farmers and indigenous peoples to achieve food security.

It is worth noting though that IP rights are only a small component of the institutional framework required to deal with the issue of food security. ${ }^{57}$ But IP policies may play a role in ensuring food security when they impede or facilitate creation of new varieties (Blakeney, 2009, pp. 234-44). It becomes thus imperative for Chile to shape its IP trade-related policy in order to promote access to food. Furthermore, the relevance of food security in the implementation of the right to food (Chiarolla, 2015, pp. 521-43; Haugen, 2005, pp. 342-51) requires human rights to prevail when hampered by private rights (GIZ Deutsche Gesellschaft für Internationale Zusammenarbeit GMbH, 2015).

\section{Subsidies}

In the agricultural sector, subsidies also play a role in agricultural innovation. It has been argued that PBRs do not reduce trade barriers when countries incentivize crop production through subsidies (Ragavan, 2007, p. 320, pp. 335-40). ${ }^{58}$ This seems to be also the case of PBRs in Chile, which may create more benefits for US breeders rather than local ones. As noticed in the above diagrams, US breeders have large portions of the Chilean market.

Besides PV certificates, US breeders receive generous subsidies from the US government (Edwards, 2009). ${ }^{59}$ US subsidies are higher than those received by Chilean farmers (Babcock, 2006, p. 3), which find themselves in a disadvantaged position because US breeders may be able to sell their varieties at lower prices. This will increase marginalization of smallholder farmers and indigenous peoples given their difficulty to compete in the market. The effect might be that of hindering productivity growth in lagging regions instead of promoting it. But the revitalization of the agricultural sector in a modernizing economy such as Chile requires an emphasis on productivity, commercialization and competiveness of traditional crops systems (Pingali, 2010, pp. 3867-79). To support this objective, the Chilean legislator should use PBRs as a development tool for all the stakeholders involved. ${ }^{60}$ A broad farmers' privilege seems to be an adequate instrument to mitigate the monopolistic effects of breeder's rights on smallholders and indigenous peoples, and at the same time preserve breeder's incentive to innovate.

For all of the above reasons, it does not appear wise to impose western standards of plant variety protection in Chile. The incentives for Western PVP are different from those of developing countries where indigenous culture and smallholder farmers require special protection. ${ }^{61}$ What works for developed countries, may reveal ineffective for the developing ones. ${ }^{62}$ History has indeed shown that countries adopt stronger IPRs as they develop from lower to higher income countries (Freeman 1995; Mercurio, 2011, 
pp. 49-50). ${ }^{63}$ At this point, the issue to be considered is whether UPOV 1991 allows for flexibilities to limit breeder's rights and introduce a broad farmers' privilege.

\section{Finding the Flexibilities in UPOV 1991}

Although UPOV 1991 provides for strong rights, it contains some exemptions such as the breeder's, experimental, the private and non-commercial exemption and the farmers' privilege. Whilst the farmers' privilege is an optional exemption, the others are mandatory.

With respect to the mandatory exemptions, authors (de Jonge and Munyi, 2015, pp. 13-5; Prifti, 2015b, p. 19) argue that smallholders' activities of saving, replanting and exchanging seeds fall under the private and non-commercial exemption. Subsistence and indigenous peoples, indeed, carry out seedsaving practices to satisfy basic family needs and have thus no commercial intent.

UPOV FAQ further clarifys that subsistence farming acts done "exclusively for the production of a food crop to be consumed by that farmer and the dependents of the farmer" are deemed to fall within the private and non-commercial acts. ${ }^{64}$ In addition, the FAQ permit subsistence farmers to exchange their seeds against other vital goods within the local community, where the legitimate interests of the breeders are not significantly affected. This clarification gives reason for two considerations. The first pertains to prohibition of seed sale, whereas the second relates to the "legitimate interests of the breeder." Seed exchange with vital goods precludes the possibility to sell seed. This means that farmers cannot obtain credit in kind as explained above whilst analyzing the UPOV 1991 bill.

With respect to the "legitimate interests of the breeder," UPOV notes suggest considering a combination of several factors whilst defining these terms in its explanatory notes on exceptions to the breeder's rights, such as the type of variety to be exempted; the size of the holding, crop area or crop value; proportion or amount of harvested crop; remuneration and changing situations. Although Prifti (2015a, pp. 21-2) elaborates on these terms in the context of the farmers' privilege (UPOV 2009a), it does not appear sensible to subject the private and non-commercial use exemption to the "legitimate interests of the breeder." In the case of smallholders and indigenous peoples, the importance of seed exchange with vital goods should prevail over the economic interests of the breeder. Moreover, the purpose of the exemption to allow private and non-commercial activities excludes an interest from the breeder. If smallholders engage in commercial activities, they will be considered as competitors and might fall under the breeder's exemption.

UPOV notes also consider traditional practices of seed-saving as part of the farmers' privilege. In this regard, some authors have already put forward a broad understanding of the farmers' privilege that includes seed-exchange (Prifti, 2015b, pp. 20-2) and have differentiated between different types of farmers in order to take account of their different incentives (de Jonge and Munyi, 2015). It appears thus that the mandatory exemption of private and non-commercial use is best suited to protect the interests of smallholder farmers and indigenous people.

\section{UPOV Flexibilities and Patents}

Despite the explicit prohibition to grant patents on plant varieties (article 37 (b) of law no. 19.039 on Industrial Property), patent rights extend to plant varieties when patented elements are inserted into a variety since patent rights have no exceptions. This means that if the Chilean legislator decides to broaden the farmer's privilege to breeder's rights, farmers' freedom to use, resow and exchange seed will be restricted if patents cover plant varieties. Besides farmers, patent rights also impede breeders to freely use patented varieties in their breeding programs. Hence, a coherent implementation of plant 
breeder's rights in Chile requires an introduction of a farmers' privilege and a breeder's exemption to patent rights.

\section{Conclusions and Recommendations}

This paper argues that UPOV standards imposed by US FTAs in Chile may not work as an incentive to foster domestic plant breeding. Although strong rights help breeders to recoup their B\&D costs and increase profits, they prevent farmers and indigenous peoples from accessing the technology embedded in the protected seed as well as from continuing their traditional breeding practices. Preserving these practices and balancing all the concerned stakeholders is necessary for designing policies that encourage sustainable development in Chile. The analysis allows concluding that it is not free trade that should be questioned, but the drafting of plant variety law in line with the national development needs. Hence the following recommendations for adopting UPOV 1991-compliant plant breeder's rights in Chile:

1. Subsistence farmers and all indigenous communities should be allowed to continue their traditional practices of saving, replanting, and exchanging seed for any kind of plant variety under the private and non-commercial exemption.

2. The farmers' privilege should be adopted and the legislator may differentiate between different types of farmers when deciding on the amount of seed to be used on farmer's own holding.

3. Seed saving should be allowed for staple crops relevant for food security independently from the breeding method (synthetic or hybrid).

4. The exhaustion of breeder's rights should end with the first sale. The further propagation of protected material should be freely permitted.

5. There should be no distinction between direct and indirect anticompetitive acts when deciding on compulsory licensing.

6. There should be no penal sanctions for farmers.

7. When granting patent rights on plants, Chile should explicitly adopt a breeder's and a farmers' exemption to patent rights.

\section{About the Author}

Viola Prifti is research fellow at the Centre for Intellectual Property Policy and Management, Bournemouth University, 89 Holdenhurst Road, Bournemouth, Dorset BH8 8EB, UK; e-mail: priftiv@bournemouth.ac.uk

\section{Notes}

The author acknowledges an initial 3-month scholarship from the Max Planck Institute for Innovation and Competition (MPIIC) in Munich for this research. However, the paper was written independently and the author is the only responsible for any mistake or non-compliance with MPIIC's research standards and objectives. The author is also responsible for the translation of documents from Spanish into English.

1. Article 17.1.3 (a) of the US Chile FTA. The text of the agreement is available at $<$ https://ustr.gov/tradeagreements/free-trade-agreements/chile-fta/final-text $>$ [Accessed 21 June 2016].

2. UPOV is an international agreement that provides for specific intellectual property rights on plant varieties. It was adopted in 1961 and entered into force in 1968. It has been revised in 1972, 1978 and 1991. Chile is currently a member of UPOV 1978. See the list of UPOV ratifications as updated on October $2015<\mathrm{http}: / /$ www.upov.int/ export/sites/upov/members/en/pdf/pub423.pdf $>$ [Accessed December 2015]. 
3. $<$ https://www.camara.cl/pley/pley_detalle.aspx?prmID=6819> [Accessed June 2016].

4. Message no. 1435-356. For a detailed account of the approval of this bill see House of Representatives of Chile, Bulletin 6426-10. Available at $<$ http://www.diputados.cl/pley/pley_detalle.aspx?prmID=6819> [Accessed June 2016].

5. See the document "Requerimiento y acompañas documentos," 20 May 2011, Tribunal Constitucional de Chile, Rol no. 1988-11-CPT of 24 June 2011. Available at <http://www.tribunalconstitucional.cl/wp/expedientes $>$ [Accessed May 2015].

6. The Chilean President Sebastian Piñera Echenique argued that UPOV is a non-self-executing act, and therefore cannot be declared unconstitutional. Nevertheless, the Constitutional Tribunal delivered judgment based on the probability of unconstitutional effects of the act implementing UPOV 1991. The Tribunal applied a preventive control in order to preserve the constitutional supremacy. For the President's opinion see "Formula Observaciones," pp. 15-8, whereas for of the decision of Tribunal see pages 32-8, of the decision of Tribunal Constitucional de Chile Rol no. 1988-11-CPT of 24 June 2011. Both documents are available at $<$ http://www. tribunalconstitucional.cl/wp/expedientes $>$ [Accessed 15 May 2015].

7. See pp. 24-79 of the decision. Tribunal Constitucional de Chile, Rol No. 1988-11-CPT of 24 June 2011.

8. Other impugned Constitutional provisions were article 19 no. 2, no. 8, no. 22. See better "Requerimiento y acompañas documentos," 20 May 2011, Tribunal Constitucional de Chile, Rol No. 1988-11-CPT of 24 June 2011. See also pp. $80-102$ of the decision. Available at $<\mathrm{http}: / /$ www.tribunalconstitucional.cl/wp/expedientes $>$ [Accessed May 2015].

9. Studies were cited in favour of the argument that PVP will contribute to replacing traditional agrosystems by monocultural varieties strongly dependent on agrochemicals, and affect foodstuffs and the environment.

10. Here the judges made a distinction between the right to property (article 19 no 23 of the Chilean Constitution) and the right on property (article 19 no 24 of the Chilean Constitution). See pages $41-6$ of the decision. The text of article 19 no. 23 is the following: "Freedom to acquire ownership over all types of property except that which nature has made common to all men or which should belong to the entire Nation, and that the law so declares. The above is without prejudice to what is prescribed in other precepts of this Constitution. When the national interest demands it, a law passed by a qualified quorum may establish limitations or requirements for acquiring ownership over specific property;" see Constitution of the Republic of Chile, Santiago, 21 October 1980.

11. See p. 58 of the decision. See also pp. 61-3 that explain the admissibility of the farmers' privilege restricted to the use of harvested material on their own holdings provided that it does not violate rights protected by the constitutional order.

12. See p. 67 of the decision. The judges recalled other national and international instruments on biodiversity preservation and access to genetic resources, such as the Convention on Biological Diversity ratified by decree no. 1963 of 1994 of the External Relations Ministry (pp. 41-61), previous judicial decisions on the matter and the guarantees to safeguard the national genetic patrimony as established both in article 1 of the law 19.342 and in article 3 of the Industrial Property Law of Chile of 9 March 2006, as last revised on 26 January 2007.

13. Commercial breeders' growth model is based on the concept of "creative destruction" (Schumpeter, 2010) whereas smallholders' innovation model can be compared to the indigenous duty of custody and use of knowledge in order to adapt to change as explained by Prof. Peter Drahos, (2014) Intellectual Property, Indigenous People, and Their Knowledge, Cambridge University Press, Cambridge.

14. The text of the bill is available at $<$ https://www.camara.cl/pley/pley_detalle.aspx?prmID $=6761 \&$ prmBoletin= 6355-01> [Accessed on May 2015].

15. Under UPOV 1978, this is not explicit but inferred from paragraphs 1 and 2 which provide for the cases that do not require the breeder's authorization. Farmers are implicitly authorized to use the protected variety without the authorization of the breeder, except for acts related to commercial production.

16. Contracting parties are required to subject this permission to reasonable limits and to the legitimate interests of the breeder. UPOV defines either "reasonable limits" or "legitimate interests." These terms are thus to be 
interpreted by national legislators. In the EU, they are taken into account by article 14 of the EC Regulation 2100/94, which provides for a list of plant varieties which can be used upon an equitable remuneration to the right holder but exempts "small farmers" from such obligation. For more information, see UPOV Explanatory Notes on Exceptions to the Breeder's Rights Under the 1991 Act of the UPOV Convention, $\mathrm{UPOV} / \mathrm{EXN} / \mathrm{EXC} / 1$.

17. See article 8 of UPOV 1978 and article 19 of UPOV 1991.

18. The legislator, however, may have seen it appropriate to codify their protection, especially after the advent of reverse breeding techniques that can track parental lines. For an understanding of these techniques see Rob Dirks et al. (2009), pp. 837-45.

19. For example, preparation of material for propagating purposes is complementary to production of propagating material.

20. Article 2, f) of the Ley Monsanto defines "harvested material" as covering both vegetatively and sexually propagating material. For an understanding of the provision on harvested material see UPOV Explanatory Notes on Acts in Respect of Harvested Material Under the 1991 Act of the UPOV Convention, October 24, 2013, UPOV/EXN/HRV/1. Available at $<$ http://www.upov.int/edocs/expndocs/en/upov_exn_hrv.pdf $>$ [Accessed June 2015].

21. For an explanation see article 2, g) of the bill. For a thorough understanding see UPOV Seminar on Essentially Derived Varieties, October 22, 2013 (Geneva, Switzerland). Available at <http://www.upov.int/edocs/pubdocs/ en/upov_pub_358.pdf $>$ [Accessed June 2015].

22. "The variety is distinct if it is clearly distinguishable by the expression of one or more important characteristics from any other variety whose existence at the date of filing the application, is well known. A well-known variety, inter alia, is the one that appears on the official lists of varieties of any country or that whose registration has been requested in any of them."

23. Although article 7 of the bill does not exclude that varieties not listed in official registers may be deemed as a "matter of common knowledge," the interpretation of "common knowledge" will be decisive in determining the "distinctiveness" requirement.

24. Although the act does not define "synthetic" seeds, conventional wisdom suggests that the terms refer to genetically modified seeds.

25. To author's knowledge, the regulation has not been enacted given the withdrawal of the bill. See article 56 of the bill establishing that the Regulation should be emanated within 180 days after the promulgation of the bill (law) in the Official Gazette.

26. For an understanding of hybridized varieties, see DuPont Pioneer's list of hybridized products. Available at $<$ https://www.pioneer.com/home/site/about/products/crops/canola/ $>$ [Accessed June 2015]. To be noticed that its canola and maize hybrids are already marketed in Chile.

27. Genetically modified crops are not allowed for domestic consumption in Chile, but they have been cultivated since 1987 and authorized for export in 1992. The main GM crops are maize, soybeans and canola. See Salazar and Montenegro (2009) pp. 353-68. See also USDA Foreign Agricultural Service, Gain Report nr. CI1021, 15 July 2011. For more information on the approved GM crops in Chile, see the GM Approval Database. Available at $<$ http://www.isaaa.org/gmapprovaldatabase/approvedeventsin/default.asp?CountryID=CL\&Country=Chile $>$ [Accessed July 2015].

28. From the wording of the provision, it may be questionable whether the farmer should be the sole proprietor of the holding or bear any kind of property title.

29. The farmer is, however, not allowed to save a larger quantity of seed than that originally acquired. For further explanations on this point see the decision of the Tribunal Constitucional of Chile, 24 June 2011, Rol No. 1988-11, pp. 62-3.

30. See Jeroen van Wijk, "How Does Stronger Protection of Intellectual Property Rights Affect Seed Supply? Early Evidence of Impact” (1996) 13 Natural Resource Perspectives. For more on informal credit markets in the Chilean 
agricultural sector, see Nisbet (1969), "The Relationship Between Institutional and Informal Credit Markets in Rural Chile" (1969) 45(2). Land Economics.

31. For a definition of "direct" see, $<$ http://www.oxforddictionaries.com/definition/english/direct $>$ [Accessed June 2015].

32. For a definition of "direct" see $<$ http://www.merriam-webster.com/dictionary/direct $>$ [Accessed July 2015].

33. Bowman vs. Monsanto Co, No. 11-796, 569 US_(2013). For more on this issue, see Lim (2015), p. 559, pp. 563-9.

34. For other US cases on this issue see Janis (2014), pp. 238-40.

35. An example is a strawberry variety developed by University of California Davis not allowed to be licenced, marketed, or produced in countries with no UPOV protection. See Jefferson et al. (2014), p. 400.

36. For further discussion, see the section “Can Plant Breeder's Rights Be Weakened?".

37. Here an issue may be that of defining differences between varieties. In this regard, it has been argued that essentially derived varieties do not enter into direct competition with the original variety. See Prifti (2015b), p. 116.

38. For a more elaborated analysis on penal sanctions see (Prifti, 2015b).

39. For an understanding of this phenomenon in a general context, see Berger and Luckmann (1991), pp. 70-89.

40. For an explanation of social change see Moore (1974). The change for farmers can be caused both by technological (GM seeds) and economic (change of breeding processes) factors.

41. Although article 52 does not preclude the possibility of applying penal sanctions.

42. Names are included in the traditional cultural expressions. For general information, see $<\mathrm{http} / / \mathrm{www}$.wipo.int/tk/ en/folklore/> [Accessed July 2015].

43. See the positions papers of the American Seed Trade Association, European Seed Association, International Seed Federation. For an historical overview of the origin of PBRs, see Kevles (2002).

44. Countries' macroeconomic policies may play a major role. This was observed with regard to Argentina in the Jaffé and van Wijk study. For an understanding of a variety of factors that influence innovation in general see Freeman (1995), pp. 5-24.

45. As Endres and Giffin note "although the lack of a statistically significant correlation does not disprove standard innovation theory, it nonetheless implies that the presumed link between intellectual property rights and plant innovation may not be as direct as previously thought and warrants further empirical research. This is of particular importance in the agricultural context, in which plant variety protection engenders complex issues of equity, subsistence farmers' rights, and government-sanctioned monopolization by multinational corporations of the basic building blocks of the human food supply." See Endres and Giffin (2012), p. 208.

46. The Heckscher-Ohlin model is a general equilibrium mathematical model of international trade that expects countries to export goods produced by their cheap and abundant factors of production and import goods that use countries' scarce factors. Note also that trade benefits accruing to developing countries depend on the size of their economies. For an understanding see Hirsch (2011), pp. 234-6.

47. Note that "economic development" differs from "economic growth." The first is a normative concept and is measured by the Human Development Index, whilst the second is a narrower concept measured by the GDP. For further discussion see Chon (2006), pp. 2821-912.

48. Source: Servicio Agrícola y Ganadero (Agriculture and Livestock Service). Available at $<$ http://www.sag.cl/ ambitos-de-accion/proteccion-derechos-del-obtentor $>$ [Accessed August 2015]. Data were last updated on 13 July 2015 and the figures do not distinguish between provisional and definitive titles.

49. Public institutions may be funded from private funds, but their largest financial assistance comes from public entities such as the Ministry of Agriculture.

50. For native plants in Chile see Timothy et al. (1961), p. 5.

51. Please, note that beans, maize, potatoes, wheat are native plants of Chile; triticale is a hybrid (barley \& rye) created by Norman Borlaug during the Green Revolution whilst most of the remaining plants originate in the Mediterranean Europe and some in Eastern Europe. 
52. For cultivated agricultural plant species see the EU Plant Variety Catalogue as an example. Available at $<$ http:// ec.europa.eu/food/plant/plant_propagation_material/plant_variety_catalogues_databases/search/public/index. cfm?event=SearchForm\&ctl_type=A $>$ [Accessed August 2015].

53. To be noted that farmers are often dependent on marketed seeds and subsistence farmers lack the resources to breed high quality seeds.

54. World bank data show a constant number of undernourished people in Chile in the recent decades. Available at $<$ http://data.worldbank.org/indicator/SN.ITK.DEFC.ZS?page=2 $>$ [Accessed January 2016].

55. See also Evangelical Church (2013).

56. This is because contrary to patents, breeder's rights contain an exemption that allows breeding with protected material.

57. Transportation systems, market structure, poverty and distribution issues play a major role.

58. For general considerations on subsidies see Lee (2011), pp. 297, 305, whilst for an elaboration of subsidies in agriculture see Ragavan (2012) pp. 319-29.

59. The database of US farm subsidies is available at <http://farm.ewg.org/>. [Accessed August 2015].

60. Bryan Mercurio suggests that developing countries should create frameworks in which IPRs are viewed as a tool for development. Mercurio (2011), p. 72.

61. The incentive for PVP comes from the breeding industry, not from farmers. Western farmers, however, are economically advantaged compared to small farmers in developing countries. Moreover, indigenous peoples are less numerous in Europe.

62. It has been noted that the Green Revolution did not bring benefits to small-scale farmers in developing countries though it advantaged those of developed countries. Ragavan (2007), pp. 324-5.

63. Chon argues that developing countries often experience negative social-welfare effects when harmonizing IP rules, Chon (2014), p. 257.

64. <http://www.upov.int/about/en/faq.html\#Q13> [Accessed August 2015].

\section{References}

Andersen, B. and Konzelmann, S. (2008) 'In Search of a Useful Intellectual Property Rights', Research Policy, 37, $12-28$.

Babcock, B.A. (2006) 'Unfair Trade: Culprits and Victims', Iowa Agriculture Review, 12(1), 1-3. Available at $<\mathrm{http}: / / w w w . c a r d . i a s t a t e . e d u / i o w a \_a g \_r e v i e w / w i n t e r \_06 / a r t i c l e 1 . a s p x>$ [Accessed August 2015].

Berger, P. and Luckmann, T. (1991) The Social Construction of Reality. A Treatise in the Sociology of Knowledge. Penguin Books, London.

Blakeney, M. (2009) Intellectual Property Rights and Food Security. CAB International, Oxfordshire.

Boldrin, M. and Levine, D. (2008) Against Intellectual Monopoly. Cambridge University Press, Cambridge.

Chiarolla, C. (2015) 'Right to Food and Intellectual Property Protection for Plant Genetic Resources', in C. Geiger (ed.), Research Handbook on Human Rights and Intellectual Property. Edward Elgar, Cheltenham, pp. 521-43.

Chipman, J.S. (2008) The Theory of International Trade: Volume I. Edward Elgar, Cheltenham.

Chon, M. (2006) 'Intellectual Property and the Development Divide', Cardozo Law Review, 27, 2821-912.

Chon, M. (2014) 'Intellectual Property and Theories of Developmental Justice', in D. Gervais (ed.), Intellectual Property, Trade and Development. Strategies to Optimize Economic Development in a TRIPS-Plus Era, $2^{\text {nd }}$ edition, Oxford University Press, Oxford, pp. 256-86.

Cimoli, M., Dosi, G., Maskus, K.E., Okediji, R.L., Reichman, J.H. and Stiglitz, J.E. (eds.) (2014) Intellectual Property Rights. Legal and Economic Challenges for Development. Oxford University Press, Oxford.

Correa, C. (2000a) Intellectual Property Rights, the WTO and Developing Countries. The TRIPS Agreement and Policy Options. Zed Books, Third World Network, Penang. 
Correa, C. (2000b) Options for the Implementation of Farmers' Rights at the National Level, South Centre, TradeRelated Agenda Development and Equity Working Papers 8.

de Jonge, B. and Munyi, P. (2015) 'A Differentiated Approach to Plant Variety Protection in Africa.' Wageningen Working Papers in Law and Governance, Law and Governance Group 2015/4.

Dirks, R. et al. (2009) 'Reversed Breeding: A Novel Breeding Approach Based on Engineered Meiosis', Plant Biotechnology Journal, 7(9), 837-45.

Dosi, G. and Stiglitz, J.E. (2014) 'The Role of Intellectual Property Rights in the Development Process, with Some Lessons from Developed Countries: An Introduction’, in M. Cimoli, G. Dosi, K.E. Maskus, R.L. Okediji, J.H. Reichman, and J.E. Stiglitz (eds.), Intellectual Property Rights. Legal and Economic Challenges for Development. Oxford University Press, Oxford, pp. 1-53.

Drahos, P. (2014) Intellectual Property, Indigenous People, and Their Knowledge. Cambridge University Press, Cambridge.

Eaton, D. (2007) 'Intellectual Property Rights in Plant Breeding and Biotechnology: A Comparative Institutional Analysis.' Paper presented at the 11th Annual Conference of the International Society for New Institutional Economics, ISNIE, Reykjavik, Iceland, 21-23 June.

Edwards, C. (2009) 'Agricultural Subsidies', Cato Institute. Available at $<\mathrm{http} / /$ www.downsizinggovernment.org/ sites/downsizinggovernment.org/files/pdf/agriculture-subsidies_0.pdf $>$ [Accessed August 2015].

Endres, A.B. and Giffin, C.E. (2012) 'Necessity Is the Mother, But Protection May Not Be the Father of Invention: The Limited Effect of Intellectual Property Regimes on Agricultural Innovation', The Columbia Science \& Technology Law Review, 14, 203-53.

Evangelical Church (2013) Biopatents and Food Security From a Christian Perspective. A study by the Evangelical Church in Germany's Advisory Commission on Sustainable Development.

Feenstra, R.C. (2004) Advanced International Trade: Theory and Evidence. Princeton University Press, Princeton. Fink, C. and Primo Braga, C.A. (2005) 'How Stronger Protection of Intellectual Property Rights Affects International Trade Flows', in C. Fink and K.E. Maskus (eds.), Intellectual Property and Development. Lessons from Recent Economic Research. World Bank, Oxford University Press, Oxford, pp. 19-40.

Food and Agriculture Organization (2014) Latin America and the Caribbean Food \& Agriculture. FAO Statistical Yearbook, Santiago. Available at <http://www.fao.org/docrep/019/i3592e/i3592e.pdf $>$ [Accessed August 2015].

Freeman, C. (1995) 'The "National System of Innovation" in Historical Perspective', Cambridge Journal of Economics, 19, 5-24.

GIZ, Deutsche Gesellschaft für Internationale Zusammenarbeit GMbH (2015) The UPOV Convention, Farmers' Rights and Human Rights. An Integrated Assessment of Potentially Conflicting Legal Frameworks. A study on behalf of the Federal Ministry for Economic Cooperation and Development, Feldafing. Available at $<$ https:// www.giz.de/fachexpertise/downloads/giz2015-en-upov-convention.pdf $>$ [Accessed August 2015].

Goldsmith, P.D., Nauriyal, D.K. and Peng, W. (2007) 'Seed Biotechnology, Intellectual Property and Global Agricultural Competitiveness', in J.P. Kesan (ed.), Agricultural Biotechnology and Intellectual Property. Seeds of Change. CABI International, Oxfordshire, pp. 19-37.

Greenspoon, R.P. and Cottle, C.M. (2011) 'Don't Assume a Can Opener: Confronting Patent Economic Theories with Licensing and Enforcement Reality', The Columbia Science and Technology Review, 12, 194 218.

Grossman, G.M. and Helpman, E. (1991), Innovation and Growth in the Global Economy. MIT Press, Cambridge, MA.

Hansen, L. and Knudson, M. (1996) 'Property Right Protection of Reproducible Genetic Material', Review of Agricultural Economics, 18(3), 403-14.

Haugen, H.M. (2005) The Right to Food and the TRIPS Agreement. With a Particular Emphasis on Developing Countries' Measures for Food Production and Distribution. Ph.D. thesis, University of Oslo, Oslo. 
Hirsch, M. (2011) 'North-South Regional Trade Agreements: Prospects, Risks, and Legal Regulation', in Y. Lee, G.N. Horlick, W. Choi, and T. Broude (eds.), Law and Development Perspective on International Trade Law. Cambridge University Press, New York, NY, pp. 225-45.

Horlick, G.N. (2011) 'Nonclusions', in Y. Lee, G.N. Horlick, W. Choi, and T. Broude (eds.), Law and Development Perspective on International Trade Law. Cambridge University Press, New York, NY, pp. 395-402.

Irwin, D.A. (2005) Free Trade Under Fire, $2^{\text {nd }}$ edition. Princeton University Press, Princeton, NJ.

Janis, M.D. (2014) 'Patenting Plants: A Comparative Synthesis', in R.L. Okediji and M.A. Bagley (eds.), Patent Law in Global Perspective. Oxford University Press, New York, pp. 213-42.

Jefferson, D.J. (2014) 'Development, Farmers' Rights, and the Ley Monsanto: The Struggle Over the Ratification of UPOV 91 in Chile', IDEA 55(1), 31-77.

Jefferson, D.J., Camacho, A.B., and Chi-Ham, C.L. (2014), 'Towards a Balanced Regime of Intellectual Property Rights for Agricultural Innovations', Journal of Intellectual Property Rights, 19, 395-403.

Kevles, D. (2002) A History of Patenting Life in the US with Comparative Attention to Europe and Canada. European Group on Ethics in Science and New Technologies to the European Commission, Brussels.

Krugman, P. (1979) 'A Model of Innovation, Technology Transfer, and the World Distribution of Income' Journal of Political Economy, 87(2), 253-66.

Krugman, P.R. (1996) Rethinking International Trade, $5^{\text {th }}$ edition. MIT Press, Cambridge, MA.

Law no. 19.039 on Industrial Property (Chile).

Law nr. 19.342 on Plant Breeder's Rights. Available at $<$ http://www.upov.int/upovlex/en/details.jsp?id=807> [Accessed December 2015].

Lee, Y. (2011) 'Free Trade Agreements and Foreign Direct Investment. A Viable Answer for Economic Development?', in Y. Lee, G.N. Horlick, W. Choi, and T. Broude (eds.), Law and Development Perspective on International Trade Law. Cambridge University Press, New York, NY, pp. 297-316.

Lim, D. (2015) 'Living with Monsanto', Michigan State Law Review 559, 559-663.

Louwaars, N. (2007) Seeds of Confusion: The Impact of Policies on Seed Systems. Ph.D. dissertation. University of Wageningen, Wageningen.

Mercurio, B. (2011) 'Intellectual Property Rights, Trade, and Economic Development', in Y. Lee, G.N. Horlick, W. Choi, and T. Broude (eds.), Law and Development Perspective on International Trade Law. Cambridge University Press, New York, NY.

Moore, W.E. (1974) Social Change, Foundations of Modern Sociology, $2^{\text {nd }}$ edition. Prentice Hall, Englewoods Cliffs, NJ.

Moschini, G. and Yerokhin, O. (2007) 'The Economic Incentive to Innovate in Plants: Patents and Plant Breeder's Rights', in J.P. Kesan (ed.), Agricultural biotechnology and intellectual property: Seeds of change. CAB International, pp. 190-203.

Nisbet, C.T. (1969) 'The Relationship Between Institutional and Informal Credit Markets in Rural Chile', Land Economics 45(2), 162-173.

Office of the United States Trade Representative (USTR) (2016) 2016 Special 301 Report, United States Trade Representative. Available at <https:/ustr.gov/sites/default/files/USTR-2016-Special-301-Report.pdf $>$ [Accessed June 2016].

Pingali, P. (2010) 'Agriculture Renaissance: Making ‘Agriculture for Development' Work in the $21^{\text {st }}$ Century', in K.J. Arrow and M.D. Intriligator (eds.), Handbook of Agricultural Economics, vol. 4. Elsevier BV, Oxford, pp. 3867-94.

Prifti V. (2015a) 'Understanding the Farmers' Privilege in 'Monsanto Laws", Social Science Research Network [online]. Available at $<$ http://papers.ssrn.com/sol3/papers.cfm?abstract_id=2708600 $>$ [Accessed January 2016].

Prifti, V. (2015b) The Breeder's Exception to Patent Rights. Analysis of Compliance with Article 30 of the TRIPS Agreement. Springer International, Cham. 
Ragavan, S. (2007) 'To Sow or Not to Sow: Dilemmas in Creating New Rights in Food', in J.P. Kesan (ed.), Agricultural Biotechnology and Intellectual Property. Seeds of Change. CABI International, Oxfordshire, pp. $320-46$.

Ragavan, S. (2012) Patent and Trade Disparities in Developing Countries. Oxford University Press, New York, NY. Rangnekar, D. (2001) Access to Genetic Resources, Gene-Based Inventions and Agriculture, Commission on Intellectual Property Rights, Study Paper 3a, London.

Ricardo, D. (1971) On the Principles of Political Economy and Taxation. Penguin Books, Harmondsworth.

Salazar, E. and Montenegro, G. (2009) 'Genetically Modified Crops in Chile’, Ciencia e Investigaión Agraira, 36(3), 353-68.

Schumpeter, J. (2010) Capitalism, Socialism and Democracy. Routledge, London.

Sen, A. (1999) Development as Freedom. Knopf, New York, NY.

Timothy, D.H., B. Pefia, V., and R. Ramirez, E., with Brown, W.L. and Anderson, E. (1961) Races of Maize in Chile. National Academy of Sciences - National Research Council, Publication 847. Washington, D.C.

Trebilcock, M. (2011) Understanding Trade Law. Edward Elgar: Cheltenham, Northampton MA.

Tribunal Constitucional of Chile, 24 June 2011, Rol no. 1988-11.

Umaña-Murray, M. (1996) Three Generations of Chilean Cuisine. Lowell House, Los Angeles, CA.

UPOV (2009a) Explanatory Notes on Exceptions to the Breeder's Rights Under the 1991 Act of the UPOV Convention, UPOV/EXN/EXC/1, Geneva, 22 October 2009.

UPOV (2009b) Explanatory Notes on Provisional Protection, UPOV/EXN/PRP/1, 22 October 2009, Geneva. Available at $<$ http://www.upov.int/export/sites/upov/en/publications/pdf/upov_exn_prp_1.pdf $>$ [Accessed June 2015].

US-Chile Free Trade Agreement. Available at $<$ https://ustr.gov/trade-agreements/free-trade-agreements/chile-fta/ final-text $>$ [Accessed December 2015].

USDA (2011) Foreign Agricultural Service, Gain Report nr. CI1021, 15 July 2011. Available at $<$ http://gain.fas.usda. gov/Recent\%20GAIN\%20Publications/Agricultural\%20Biotechnology\%20Annual_Santiago_Chile_7-152011.pdf $>$ [Accessed July 2015].

van Wijk, J. (1996) 'How Does Stronger Protection of Intellectual Property Rights Affect Seed Supply? Early Evidence of Impact', Natural Resource Perspectives 13. Available at $<$ https://www.odi.org/sites/odi.org.uk/ files/odi-assets/publications-opinion-files/2965.pdf $>$ [Accessed July 2015]. 